\title{
The Holy Spirit and the early Church: The experience of the Spirit
}

\author{
Author: \\ Johannes van Oort ${ }^{1,2}$ \\ Affiliations: \\ ${ }^{1}$ Radboud University \\ Nijmegen, The Netherlands \\ ${ }^{2}$ Faculty of Theology, \\ University of Pretoria, \\ South Africa \\ Note: \\ Prof. Dr Johannes van Oort \\ is Professor Extraordinarius \\ in the Department of Church \\ History and Church Polity of \\ the Faculty of Theology at \\ the University of Pretoria, \\ South Africa.

\section{Correspondence to:} \\ Hans van Oort \\ Email: \\ j.van.oort@planet.nl \\ Postal address: \\ Van Renesselaan 24, $3703 \mathrm{AH}$ \\ ZEIST, The Netherlands

\section{Dates:} \\ Received: 27 July 2011 \\ Accepted: 22 Dec. 2011 \\ Published: 14 Mar. 2012 \\ How to cite this article: \\ Van Oort, J., 2012, 'The Holy \\ Spirit and the early Church: \\ The experience of the Spirit', \\ HTS Teologiese Studies/ \\ Theological Studies 68(1), \\ \#Art. 1154, 7 pages. http:// \\ dx.doi.org/10.4102/hts. \\ v68i1.1154
}

(C) 2012. The Authors. Licensee: AOSIS OpenJournals. This work is licensed under the Creative Commons Attribution License.
Firstly, the present article explored the occurrence of special gifts of the Holy Spirit (charismata) both in the New Testament and in a number of early Christian writers (e.g. Justin Martyr, Irenaeus, Tertullian and Augustine). Secondly, it indicated how this experience of special charismata exerted its influence on the formulation of the most authoritative and ecumenical statement of belief, viz. the Creed of Nicaea-Constantinople (381).

\section{Introduction}

My previous article in this journal (Van Oort 2011) gave an outline of the development of the doctrine about the Holy Spirit ${ }^{1}$, with specific reference to ecclesiastical writers of both the Eastern and Western traditions. In that article, I also examined the development of early Christian confessions, during which it was noticed that early Christian creedal formulas always display a tripartite structure. The reason for this structure was mainly that baptismal candidates were immersed three times, each immersion coinciding with a question and answer about each of the three persons of the Trinity respectively. These formulas eventually developed into fixed symbols. As such, it is understandable why creeds from both the West and the East, such as the so-called Apostle's Creed or Symbolum Apostolorum, as well as the Creed of Nicaea of 325 (which was endorsed and supplemented at the council of Constantinople in 381 and should therefore officially be termed the Creed of Nicaea-Constantinople), all speak of the Holy Spirit in their third sections. Because I have already examined both the development of the doctrine and the confession of the Holy Spirit, I will focus presently on the early Church's experience of the Holy Spirit, asking questions such as: How did practical experience of the Holy Spirit transpire? What phenomena accompanied such experience? What was the Church's response to all this? In answering these questions, I will once again show that, in the early Church, dogma, confession and practical experience were closely connected.

\section{The working of the Spirit and the charismata}

Readers of the New Testament will find that it speaks of the Holy Spirit often and in a multifaceted way. It is rather impossible to summarise all these characteristics and workings of the Spirit in a few sentences. The authors of the New Testament speak of the all-encompassing work of the Spirit in both the world and mankind, as well as the inhabitation of the Spirit within Christian believers, the gifts of the Spirit and baptism, the specific guidance of the Spirit; the fruit of the Spirit (as summarised in Gl 5:22f.) and so forth. We will presently confine ourselves to some specific gifts of the Spirit, the so-called charismata, as these can be found in both the New Testament and the writings of the early Church.

The noun charisma occurs only in the Pauline letters of Romans and 1 and 2 Corinthians, in 1 and 2 Timothy and once in 1 Peter (v. 4:10). In Koine Greek, the term means 'gift' or 'favour', but the word seems to have been imported into the Christian vocabulary through the Apostle Paul, receiving the technical meaning of 'gift of the Spirit' (Conzelmann 1973:392-397; Ebertz 1999:113-115; Schütz [1981] 1993:688-693).

The writings of Paul present us with three lists of specific charismata. These list appear in Romans 12:6-8, 1 Corinthians 12:8-10 and 1 Corinthians 12:28 (cf. Eph 4:11). Paul is not our only source in this regard. The rest of the New Testament also mentions specific gifts of the Spirit, albeit rather haphazardly. One may assume that, in his explicit enumerations, the apostle did not mean to provide a comprehensive list of existing charismata, but rather just some examples. The charismatic workings of the Spirit cannot be summarised in some list, because the Spirit blows where he wishes and works as he wishes (Grossmann 1980:18-121).

1.Abbreviations of original source editions: $\mathrm{CCL}=$ Corpus Christianorum, Series Latina; MPG = J.-P. Migne, Patrologiae cursus completus, Series Graeca; SC = Sources Chrétiennes. 
In 1 Corinthians 12:8-10, we find a summary list of nine successive charismata, namely speaking in wisdom, speaking in knowledge, faith (cf. 1 Cor 13:2), gifts of healing, works of powers (energèmata dynameōn), prophecy, the ability to distinguish between spirits, speaking in different kinds of tongues (litt. sorts/species of tongues: genè glōssōn) and explaining various tongues (hermèneia glōssōn). With varying degrees of satisfaction, one will discover the different meanings behind each of these charismata in New Testament commentaries (especially Thiselton 2000:936-989; cf. Thiselton 2004). Oftentimes, it is not exactly clear what Paul had in mind when he mentions each of these charismata. The cases of 'works/deeds of power' or 'speaking in/with wisdom' (litt. 'word of wisdom': logos sophias) or 'speaking in/with knowledge' (litt. 'word of knowledge': logos gnōseōs), for instance, are relatively arbitrary and their meanings not unambiguously certain. Nonetheless, with regard to some of the charismata, one can speak with more clarity. In this article, we will focus particularly on the charismata of healing, prophecy and tongues, which will lead to the most important question for the present context: How did these gifts function in the first centuries of the Christian era and how did they contribute to the development of a doctrine and confession of the Holy Spirit?

\section{Healing, prophecy, glossolalia}

Firstly, we look at the charisma of healing. This gift occurs in manifold forms within the New Testament. Not only in the Gospels, but also in Acts and the Epistles, healing is a sign of the power of God's kingdom. The Apostle Paul mentions it thrice in 1 Corinthians 12 (v. 9, 28 and 30) and, in all instances, uses a double plural form: charismata iamatōn, 'gifts for (or of) healings'. The plural of charismata seems to indicate that there were various kinds of healing. In a similar fashion, the New Testament distinguishes more than one type of curative prayer. There are prayers accompanied by the laying on of hands, prayers for an absent sick and prayers accompanied by the anointing with oil (Ja 5:14ff.). The plural form 'healings' probably indicates that many different diseases are meant, somatic as well as psychological, in all their different forms.

Secondly, there is the charisma of prophecy. The New Testament mentions prophets such as Agabus, an itinerant prophet from Jerusalem (Ac 11:28; 21:10ff.) and the daughters of Philip (Ac 21:9), but Judas and Silas (Ac 15:32) are also called prophets, as well as John ( $\operatorname{Rv} 1: 3$; cf. 1:9ff.; 22:7, 9f.). Prophecy occurs in almost all books of the New Testament as a sign of the eschatological presence of the Spirit. What does prophecy generally include? The New Testament writings refer to activities such as 'speaking for the edification, exhortation and comfort' of believers (1 Cor 14:3), sharing particular revelations (Ac 13:1f.; 1 Cor 14:26; 15:51; Rv 2-3; 22:6-19) and, closely linked to the former, foretelling future events (Ac 11:28; 21:10ff. and John's Revelation). Yet, it is necessary to emphasise that, in this brief inventory of activities and selected texts, a very limited number of features related to the wide-ranging phenomenon of early Christian prophecy are indicated. Thematic studies reveal numerous additional aspects of the specific charisma (Ellis 1978:129-144; Reiling 1973:5-19; Reiling 1977 2; cf. e.g. Aune 1983, 2003). In the present context, I merely want to draw attention to the (at times, forgotten) fact that early Christian prophecy was, amongst other things, also essential to the passing down of Jesus' words and stories about his deeds. Prophecy was, therefore, in no small way, also responsible for the genesis of the Gospels (e.g. Aune 1983:233-245, 2003:1703; Ellis 1977:51; Vielhauer 1961:634).

Thirdly, there is the charisma of glossolalia. In the classical movement, but frequently also in the new Pentecostal and other 'charismatic' movements, this charisma received the most attention. Oftentimes it is considered to be the most important and, in any case, the most eye-catching and typical gift. However, every careful reader of the Pauline texts will discover that glossolalia is but one of the many gifts mentioned in his lists of charismata. Moreover, the apostle stresses that, whilst one believer receives this gift, another believer will receive that gift (1 Cor 12:19). Nowhere is it said that 'speaking in tongues' is a charisma that all Christians should have.

Yet, that it is considered to be an important charismatic gift, is nonetheless evident. What is meant by this charisma? Paul indicates that it has to do with the speaking of, praying in and singing in a language unknown to the speaker. Glossolalia consists of ecstatic utterances; it is language of the unconscious, spoken by a person whilst being enraptured by the Spirit. Unlike prophecy (which is directed at humans), glossolalia is directed at God. This language of the unconscious becomes capable of consciousness through interpretation (hermèneia). Most modern exegetes agree that the phenomenon discussed by Paul in 1 Corinthians 12-14 differs from the experience of Jesus' disciples at Pentecost (Ac 2). In 1 Corinthians, we encounter a language that is also spoken in heaven and that expresses a familiar relation with God (1 Cor 13:1). This language is accessible to others who are touched by the Spirit. The explanation or interpretation of tongues (hermèneia glōssōn, 1 Cor 12:10; cf. 14:26) may be described as the 'intelligible articulation of tongues-speech' (Thiselton 2000:970). This 'articulation' is necessary and ensures that the tongues-speech is beneficial to other members of the congregation. Perhaps Augustine has the same phenomenon of 'tongues' in mind when, in his explanation of Psalm 33:3 ('shout for joy'), he speaks of jubilatio as a wordless speech: 'Sing in jubilation ... What is to sing in jubilation? It is to be unable to express in words what is sung by the heart' (CCL 38, $254^{3}$; cf. Thiselton 2004:209).

\section{A particular privilege of the early Church?}

The foregoing paragraphs offered a very concise summary of charismata as they occur within the New Testament,

2.See, for example, page $66 \mathrm{ff}$. on the various kinds of prophets and page 69 on the functions of apostle-prophet-teacher.

3.In iubilatione cane ... Quid est in iubilatione canere? ... uerbis explicare non posse quod canitur corde'. 
focusing on the gifts of healing, prophecy and glossolalia. The significant question now becomes: Should these and other special charismata be regarded as a 'peculiar privilege of the apostolic and primitive church' (peculiare privilegium ecclesiae apostolicae et primitivae)? In past centuries, the gift of special charismata was often considered to be appropriate only for the very first time of diffusion of the gospel. Even so, several church fathers did not accept this view (Ritter 1972:197-200). Ages later, during the Protestant Reformation, such a view was also not the common opinion. Werner Krusche (1957:331) mentions that Calvin, in spite of an acute prudence towards all sorts of religious 'fanatics', did not understand specific gifts of the Spirit to be only historically interesting (cf. Van der Linde 1943:74-75). ${ }^{4}$ Besides, in recent decades, Pentecostal movements posed novel questions to the 'official' churches, as had been done in the past (see e.g. the classical work by Ronald Knox 1950). In particular, the universal emergence of charismatic movements brought with it a new consciousness of the biblical charismata and their significance to the contemporary Church.

In the following paragraphs, the manner in which the gifts of prophecy, healing and glossolalia occurred within the early Christian Church will be discussed. In order to prevent a misleading perspective, it is imperative to note, firstly, that the Montanist movement caused an immense uproar in the 2nd century, finally necessitating a strong defensive reaction. The very first Church synods were held in Asia Minor in reaction to this movement (Eusebius, Historia Ecclesiastica $5,16,4$, ed. Lake, I, 472). After initially struggling with the subject, these councils ended up severely condemning 'the new prophecy'. But perhaps they threw out the baby with the bathwater? The famous Church history writer, Walter Nigg (1905-1988), once argued that the Church, in dealing with the Montanists, barricaded itself against prophecy and in the process condemned its own past (1949:99).

\section{Montanism}

Yet, this view is not free from subjectivity and a certain level of prejudice. It is still not completely clear exactly what Montanism entailed (Frend [1994] 2000; Tabbernee 2007, 2009; Trevett 1996). We know that the 2nd-century apocalyptic movement expected a speedy outpouring of the Holy Spirit and saw the first manifestations of this outpouring in their own leaders. Montanus began preaching in Phrygia around 172. Additionally, there are minor reports of the performances of two prophetic women, Prisc(ill)a and Maximilla. But apart from these and other scanty data, supplemented by a few (sometimes recent) discoveries of archaeological remains (cf. e.g. Tabbernee \& Lampe 2008), the primary sources are scarce. The only information we

4.Discussing the many kinds of particular charismata in Protestant and closelyrelated Christian traditions falls outside the scope of this paper; nevertheless, I believe a summary of these would prove useful in understanding their context. In short, these charismata included, (1) laying on of hands and healing with prayer, which were striking features of both Luther's and Melanchthon's ministries, (2) (3) the charismatic life displayed by the Waldensians and so-called Lollards and (3) the charismatic experiences that we are told were part and parcel of the faithexpressions of persecuted Huguenots, Quakers, Moravians, early Methodists, the Blumhardts, and others. have on Montanism seems to come from the writings of their opponents. Was Montanism initially an orthodox movement - orthodox, because the 2nd-century polemic does not raise any charge of dogmatic deviation - which only later became heretical? Was Montanism an expression of false prophecy? Was their glossolalia similar to the phenomenon mentioned in the New Testament? Or is it possible that the Church's main objection was against the ecstatic character of the Montanists' prophecy? The church father Jerome opined that Montanus was under the influence of native Phrygian cults, but modern research has denied such a straightforward connection (e.g. Schepelern 1929). Still, much is uncertain. Of the (in all probability) considerable amount of Montanist writings, only some twenty sayings have remained. Most of these Montanist sayings derive from the lost works of their first opponents and were only handed down by later Christian writers. Above all, it is Eusebius who provides important material in his Historia Ecclesiastica (Book 5, ed. Lake, I, 443, 471ff; cf. Aland 1960:1117-1118).

On the other hand, could it be that Montanism was an extreme variety of Johannine Christianity (cf. Hill [2004] 2006: e.g. 147-148), blended with supplementary archaic, Judaeo-Christian elements alive in Asia Minor (Ford 1966)? The word 'paraclete', as designation for the Holy Spirit, is indeed typical of John's Gospel and the expectation of a thousand-year period of blessedness reminds us of John's Revelation (ch. 20). The burning desire for martyrdom and the stress on abstinence also point to the particular influence of the Book of Revelation. It is characteristic that, according to ancient traditions (cf. ed. Cross \& Livingstone 2005:649), the presbyter Gaius of Rome did not only reject Montanism, but also the Gospel of John and the Book of Revelation. On the other hand, the martyrs of Lyon and Vienne, who were closely connected to the Christians of Asia Minor, intervened on behalf of the Montanists in Rome (e.g. Jaschke 1976:148f.). ${ }^{5}$

Montanism remains difficult to assess with regard to both the movement in general and its individual traits such as prophecy, visions, chiliasm, asceticism and calls to martyrdom. The movement later grew into an orderly church, so much so that the very influential African theologian, Tertullian, went over to these enthusiastic Christians (Augustine, De haeresibus 86; CCL 46, 338). Within this context, it is of pivotal importance to realise that ever since the condemnation of Montanism, the 'official' church has maintained a reserved stance towards the special charismata. Nevertheless, these spiritual phenomena did indeed occur within mainstream Christianity. It is possible to prove this latter statement by drawing on various testimonies from both the periods before and after the so-called 'Montanist crisis' (De Labriolle 1913). The following sections provide a small chronological selection of such testimonies.

5. Kraft (1980:250-266) supposes that the conflict was initiated, more than 5.Kraft (1980:250-266) supposes that the conflict was initiated, more than (1973:71-72) states that 'In the Montanist crisis the lack of parakolouthèsis, of (1973:71-72) states that 'In the Montanist crisis the lack of parakolouthesis, of
conscious control, is one of the most significant criteria by which Montanism is revealed as a false prophecy.' 


\section{The Didache, Justin and Irenaeus on the charismata}

The Didache or Teaching of the Twelve Apostles, a church manual that likely originated in Syria/Palestine in c.100, still deals with the gift of prophecy as if it were a standard affair within the Church. The phenomenon is described by the document as something that embodies the itinerant, charismatic prophet. Chapters 11-13 provide certain criteria by which true and false prophets should be distinguished:

You must not test or judge any prophet who speaks in the Spirit. For every sin will be forgiven, but this sin will not be forgiven. Not everyone speaking in the Spirit is a prophet, but only when he follows the lifestyle of the Lord. From their lifestyle, therefore, will the false prophet and the (true) prophet be recognized. (Didache 11, 7-8; SC 248, 184-186; cf. Holmes 2007:362-363).

It is also said that prophets are allowed to give thanks however they wish at Eucharist (Didache 10, 7; Holmes 2007:360-361).

Around c.155-160, Justin Martyr, born in Flavia Neapolis (ancient Shechem, modern Nablus), said in his Dialogue with Trypho that the prophetical gifts formerly belonging to the Jews are now at work in the Church (Dialogus cum Tryphone 82, 1; Goodspeed 1914:194; Marcovich 1997:212). In this text, he also mentions other charismata: '... for one receives the Spirit of understanding, another of counsel, another of strength, another of healing, another of foreknowledge, another of teaching, and another of the fear of God ...' (Dialogus 39, 2; Goodspeed 1914:136; Marcovich 1997:135). In the same writing (Dialogus 87, 2), and in repeated reference to Isaiah 11:2-3, he yet again mentions the seven gifts of the Spirit, a theme that became fundamental to the later Christian tradition. In his (second) Apology, Justin deals in no short way with the contemporary healings of demon-possessed persons in Rome, describing such healings as gifts of the Holy Spirit (Apologia II, 5-6; Krüger 1968:65; cf. Marcovich 1994:38-40).

In about 185, Irenaeus of Lyon provides additional testimony, vital to our present purpose. This first great church father may be characterised as a theologian of the Holy Spirit. He supplies us with a great deal of information about glossolalia, prophecy and healing, as is evident from the following two citations. It is clear that this bishop of Lyon (in ancient Gaul) thinks of the charismata as living realities in the church of his time:

Therefore, the apostle also says: 'We speak wisdom among the perfect' (I Cor. 2:6). With 'the perfect' he means those who have received the Spirit and who speak in all tongues (omnibus linguis) through the Spirit, as he himself also used to speak. In like manner, we also hear that many brethren in the church, who have prophetic charismata, speak in all kinds of tongues (universis linguis/pantodapais ... glōssais) through the Spirit and reveal the hidden things of people, for their benefit ${ }^{6}$, and explain the mysteries of God ... (Adv. Haer. 5, 6, 1; SC 153, 73f.)

6.Or:'to the general benefit'. The passage preserved in Latin reads: ad utilitatem See SC 153, 74 and also Harvey (1857, vol. II:334). The original Greek fragment is preserved in Eusebius's Ecclesiastical History V, 7, 5 and reads 'epi tooi sympheronti', which Kirsopp Lake (Lake [1926] 1975, vol. I:455) translates as 'for the common which
good'.
For some (of Christ's true disciples) do certainly and truly drive out demons, so that those who are thus cleansed from the evil spirits often believe and join the church. Others have foreknowledge of future things, they see visions and utter prophetic words. Again others heal the sick by laying their hands upon them and let them rise up healthy. Moreover, as we have said, the dead even have been raised up and lived with us for many years. What shall I say further? It is impossible to name the number of all charismata, which the church, dispersed throughout the whole world, has received from God, in the name of Jesus Christ, who was crucified under Pontius Pilate, and which she exerts day by day for the benefit of the gentiles, without misleading anyone or accepting money ... (Adv. Haer. 2, 32,4 , SC 294, 340-342)

These two quotations ${ }^{7}$ already give a good impression of Irenaeus's acquaintance with specific charismata. What he mentions is no trifling matter, although his polemic against the so-called Gnostics suggests the presence of at least some exaggeration in his statements. Nonetheless, in view of the earliest Church's testimonies (cf. e.g. Mk 16 and Heb 2:4), there is no real reason to view all of Irenaeus's statements as pure exaggeration. It is important to note that (more than once) he also addresses those from his own church who fail to accept these charistmata. For example, at the end of his Demonstratio, he writes:

Others do not accept the gifts of the Holy Spirit and cast the prophetic charisma far from their sight, through which man, when he is sprinkled with it, bears the life of God as fruit. These are the people of whom Isaiah said: 'Because (these), he says, will be like a terebinth tree that has lost all its leaves and like a garden without water' (cf. Isa. 1:30). And people like that have no use for God, because they bear no fruit. (Demonstratio 99; cf. SC 62, 169 and SC 406, 218-220)

According to Irenaeus, it is essential that prophecy and other gifts of the Spirit are embedded in the life of the Church. The decisive criterion for the authenticity of the charismata is that they are inspired by love, meaning that they serve to benefit the whole congregation (Adv. Haer. 4, 33, 7; SC 100, 816). Thus, the true Church is recognised by its charismata.

\section{Tertullian, Augustine and others}

Similarly, Tertullian declared shortly after the year 200 that one can know the true Church by its charismata (Adv. Marcionem 5, 18, 22; CCL 1, 688; cf. Bender 1961:162-163). He mentions, amongst other things, prophecy, visionary experiences, spontaneous prayer, glossolalia and healings as gifts of the Spirit. However, Tertullian, who was so influential in the Church of North Africa, became a Montanist and might even have formed his own group within the movement. ${ }^{8}$ This may alert us to regard his utterances about specific charismata with a fair bit of care and scepticism.

7.See also, for example, Adv. Haer. 2, 31, 2; 2, 32, 5; 3, 5, 2; 4, 20, 6; 5, 22, 2

8. In the footsteps of Augustine (De haeresibus 86; CCL 46, 338-339), it is usually stated that the 'Tertullianists' were a separate movement within the Montanists. Yet, this seems to be doubtful (Powell 1975:33-54). Powell (1975:53) states: 'Not only in Tertullian's writings is there no suggestion of a split among the African followers of the New Prophecy, there is nothing that can be regarded as the possible build-up for a split, and it was long ago suggested [by J M Fuller in 1887] that "Tertullianistae" was simply a name for African Montanists'. Powell (1975:38-39) himself even considers the 'Tertullianists' to be a group within the Catholic church, one ecclesiola in ecclesia, comparable to the Puritan classes in the Church of England. 
Be that as it may, specific charismata are also mentioned in Tertullian's pre-Montanist writings, where he expressly names activities that were common practice in the Christian congregation(s) of Carthage. A quotation from his writing On baptism may illustrate this point. Tertullian addresses those who are preparing for baptism as such:

Therefore, you, the blessed ones, whom the grace of God awaits, when you arise from that most holy bath of rebirth and, for the first time, stretch out your hands with your brothers ${ }^{9}$ to your mother (= the church), ask from the Father, ask from the Lord, as a special gift of His grace, the distributions of the charismata. (De baptismo 20, 5; CCL 1, 295; SC 35, 96) ${ }^{10}$

Evidently, Tertullian saw baptism, the receiving of the Spirit and the charismata as being closely linked.

Owing to a lack of space, a more comprehensive overview of the many data regarding the special charismata in the Western and Eastern churches of the first centuries cannot be given here. Significant material may be found, amongst other texts, in the Shepherd of Hermas (Rome, c.140-c.155), the writings of Cyprian (Carthage, d.258), Hippolytus (Rome, c.170-c.236) ${ }^{11}$, Clement of Alexandria (c.150-c.215), Origen (c.185-c.254), Ephraem Syrus (c.306-373) and Augustine (354-430). Concerning the latter, it is noteworthy to observe that, in his earlier writings, he accepted the common idea of his time that the particular charismata were only applicable to the origins of the Church, when the Gospel still had to be diffused. Since the Gospel had, by Augustine's time, already been spread throughout the Roman Empire and even beyond, the special charismata were no longer deemed necessary. At the end of his life, however, in the final paragraphs of his great work On the City of God (De civitate Dei 22, 8; CCL 48, 815-827; cf. Stolz 1926 and, most recently, Schindler 2009, esp. 124-129), he claimed that particular gifts of the Spirit (such as the gift of healing) were present during his own time and within his own geographical region, the North African world.

\section{The necessity for further research}

When dealing with the particular gifts of the Spirit and when considering the plenitude of diverse views on such charismata, both in the early Church and in later centuries, one gets the impression that much research can, and must, still be done. A wide assortment of questions remain unanswered. Is there a direct connection between the appearances of particular charismata and strong eschatological expectations? This does indeed seem to be the case, but why and how? Did the conversion of the Emperor Constantine and the ensuing 'Constantinian shift' (313) entail a dramatic change in the occurrence of charismatic gifts in the official Church? The answer to this question seems to be affirmative as well, but we do not know the precise reason(s) for this. Moreover, the ancient problem of the influences of Greek philosophy

9.Directly after baptism, the baptised pray the Lord's prayer with outstretched hands

10.Refoulé (SC 35, 96 n. 6) observes that 'Charisme présente ici un sens large, et désigne l'ensemble des graces énuméréés par S. Paul dans I Cor 12. Devenu
montaniste, Tertullien n'emploiera plus guère ce terme que pour designer le don de prophétie'. See also Bender (1961:144).

11.According to tradition, the Greek title of one of his works is Peri charismatoon, 'On the charismata', but unfortunately the work itself is lost. on early Christian spirituality should receive renewed attention: Irénée Hausherr (1935:114-138) once based an argument for a change in spirituality (from 'spiritualité primitive' to 'spiritualité intellectualiste') on the fact that the official Church embraced the Greek intellectual tradition. What is particularly important as well is the problem of the relation between particular charismata in the Christian church and similar expressions in Judaism (e.g. Bousset \& Gressmann 1966:394-399; cf. e.g. Brock 1967; Spittler 1983; see also Forbes 1995:183-186 on the so-called Testament of Job). Similar expressions are also to be found in Greek religions, for example (Forbes 1995:103-148; Nilsson 1974:311; Reiling 1973:73-96), as well as in present-day missionary situations. Here, too, much is still unclear.

\section{Constantinople 381 Dogma, confession, experience}

In the preceding paragraphs, a number of observations about the early Church's experience of the Holy Spirit have been made. I now return to a very particular description of the experience of the Spirit - a description formulated at a pivotal point in the early history of the Church, a time of heavy theoretical deliberations and shortly before the formulation of the Creed that became the Church's most authoritative and ecumenical statement of belief.

In 381, a church assembly was held in Constantinople. This synod was later counted as the second ecumenical council. From several testimonies we know that this council was conducted in a rather 'unspiritual' fashion. The famous Gregory of Nazianzus, for instance, called the gathering of the very venerable fathers a troupe of screeching crows and even called the participants a terrible gang (cf. e.g. Junck 1974:136). Yet, in spite of much confusion and strife, the Creed, which speaks at length about the Holy Spirit, was formulated. During the council, most probably at the inauguration of Gregory of Nazianzus as patriarch of Constantinople, Gregory of Nyssa delivered a speech called 'On his ordination' (In suam ordinationem; for date and place, see e.g. Ritter 1968). In this speech, he complained about the lack of actual experience of the Spirit in his own time and place. 'But luckily', he remarked to the gathered bishops, 'there are a few persons present here who are full of the Spirit, namely men from Mesopotamia. There, the charismata are still a living reality; there the preached Word is confirmed by the Spirit':

Perhaps someone will say that then, for the apostles, the miracles assisted and the Word was considered to be credible because of the charismata. I also mean that mighty deeds possess much persuasive power. But what must be thought of the present situation? Do you not see similar works of faith? I consider the great deeds of our fellow servants as such wonders. They testify, living in the Spirit, through the power of healing for the truth of the Word. Men came from far, they are countrymen of our father Abraham, they came from Mesopotamia ... According to their outward appearance they are old men, venerable persons to see, with shiny white hair and their mouths shut in silence. They do 
not know of (dialectical) fighting with words, they did not learn to dispute. But they have such a great power over the spirits that, with one command, they are able to do drive out the demons, not by the art of rhetoric, but through the power of faith ... (Jaeger \& Langerbeck 1967:337-338)

This testimony, once again, bears witness to the fact that the confessional sentences about the Holy Spirit in the NicenoConstantinopolitanum were based on knowledge of actual experiences of the Spirit. This fact may further contribute to a deeper understanding of the Creed's wording:

And (we believe) in the Holy Spirit, the Lord and Giver of life, who proceeds from the Father,who with the Father and the Son together is worshipped and glorified, who has spoken through the prophets.

\section{Acknowledgements Competing interests}

The author declares that he has no financial or personal relationship(s) which may have inappropriately influenced him in writing this article.

\section{References}

Aland, K., 1960, 'Montanismus', in Die Religion in Geschichte und Gegenwart, Dritte Auflage, Band IV, pp. 1117-1118, Mohr, Tübingen.

Aune, D.E., 1983, Prophecy in early Christianity and the ancient Mediterreanean world, Eerdmans, Grand Rapids, MI.

Aune, D.E., 2003, 'Prophet/Prophetin/Prophetie: IV. Christentum: Neues Testament/ Alte Kirche', in Die Religion in Geschichte und Gegenwart, Vierte Auflage, pp 1702-1705, Mohr Siebeck, Tübingen.

Behm, J., 1933, 'Glōssa', in Theologisches Wörterbuch zum Neuen Testament, Band I, pp. 719-725, Kohlhammer, Stuttgart.

Bender, W., 1961, Die Lehre über den heiligen Geist bei Tertullian, Max Hüber München.

Bousset, W. \& Gressmann, H., 1966, Die Religion des Judentums im späthellenistischen Zeitalter, Mohr, Tübingen.

Brock, S.P., 1967, 'Testamentum Iobi', in A.M. Denis \& M. De Jonge (eds.) Pseudepigraphia Veteris Testamenti Graeci II, pp. 81-96, E.J. Brill, Leiden.

Conzelmann, H.G., 1973, 'Charismata', Theologisches Wörterbuch zum Neuen Testament, Band IX, pp. 392-397, Kohlhammer, Stuttgart.

Cross, F.L. \& Livingstone, E.A., 2005, The Oxford dictionary of the Christian Church, 3rd edn., Oxford University Press, Oxford.

Crouzel, H., 1976, 'Geist (Heiliger Geist): Väterzeit', in Reallexikon für Antike und Christentum, Band IX, pp. 510-545, Anton Hiersemann, Stuttgart.

Dautzenberg, G., 1975, Urchristliche Prophetie: Ihre Erforschung, ihre Voraussetzungen im Judentum und ihre Struktur im ersten Korintherbrief, Kohlhammer, Stuttgart.

De Labriolle, P., 1913, La crise montaniste, E. Leroux, Paris.

Ebertz, M.N., 1999, 'Charisma', in Die Religion in Geschichte und Gegenwart, Vierte Auflage, n.p., Mohr Siebeck, Tübingen.

Ellis, E.E., 1977, 'Prophecy in the New Testament Church-and today', in J. Panagopoulos (ed.), Prophetic vocation in the New Testament and today, pp. 46-57, E.J. Brill, Leiden.

Ellis, E.E., 1978, Prophecy and hermeneutic in early Christianity: New Testament essays, Mohr, Tübingen.

Forbes, C., 1995, Prophecy and inspired speech in early Christianity and its Hellenistic environment, Mohr, Tübingen.

Ford, J.M., 1966, 'Was Montanism a Jewish-Christian heresy?', Journal of Ecclesiastical History 17, 145-158. http://dx.doi.org/10.1017/\$0022046900052477

Frend, W.H.C., [1994] 2000, 'Montanismus', in Theologische Realenzyklopädie, Band 23, Walter de Gruyter, Berlin.

Goodspeed, E.J., 1914, Die ältesten Apologeten, VandenHoeck und Ruprecht, Göttingen.

Grossmann, S., 1980, Genadegaven in ecenwicht: Van charismatische beweging tot charismatische gemeentevernieuwing, Kok, Kampen.

Harvey, W.W., 1857, Sancti Irenaei episcopi Lugdunensis Libros quinque adversus Haereses, ed. W. Wigan Harvey, Tom. II, Typis Acdemicis MDCCCLVII, Cambridge.

Hausherr, I., 1935, 'Les grands courants de la spiritualité orientale', Orientalia Christiana Periodica 1, 114-138.
Hennecke, E. \& Schneemelcher, W., 1964, Neutestamentliche Apokryphen..., Band II, Mohr, Tübingen.

Hill, C., [2004] 2006, The Johannine Corpus in the early Church, Oxford University Press, Oxford.

Holmes, W., 2007, The Apostolic Fathers: Greek texts and English translations, 3rd edn., ed. and transI. M.W. Holmes, after the earlier work of J.B. Lightfoot and J.R. Harmer, Baker Academic, Grand Rapids, MI.

Irenaeus, 1962, Demonstration: Irénée de Lyon, Démonstration de la prédication apostolique. Nouvelle traduction de l'arménien avec introduction et notes par L.M. Froidevaux (SC 62), Éditions du Cerf., Paris.

Irenaeus, 1969, Against Heresies: Irénée de Lyon, Contre les hérésies, Livre V, Édition critique par Adelin Rousseau, Louis Doutreleau, Charles Mercier, Tome I + II (SC 152-153), Éditions du Cerf, Paris.

Irenaeus, 1982, Against Heresies: Irénée de Lyon, Contre les hérésies, Livre II, Édition critique par Adelin Rousseau et Louis Doutreleau, Tome I + II (SC 293-294), Éditions du Cerf, Paris.

Irenaeus, 1995, Demonstration: Irénée de Lyon, Démonstration de la prédication apostolique, Introduction, traduction et notes par Adelin Rousseau (SC 406) Éditions du Cerf, Paris.

Jaeger, W. \& Langerbeck, H. (eds.), 1967, Gregorii Nysseni opera, vol. IX, E.J. Brill, Leiden.

Jaschke, H.J., 1976, Der Heilige Geist im Bekenntnis der Kirche: Eine Studie zur Pneumatologie des Irenäus von Lyon im Ausgang vom altchristlichen Glaubensbekenntnis, Aschendorff, Münster.

Junck, C., 1974, Gregor von Nazianz, De vita sua, herausgegeben, eingeleitet und übersetzt von Chr. Junck, Winter Verlag, Heidelberg.

Knox, R.A., 1950, Enthusiasm: A chapter in the history of religion, Oxford University Press, Oxford.

Kraft, H., 1980, 'Die Lyoner Märtyrer und der Montanismus', in Pietas. Festschrift für B. Kötting, n.p., Aschendorff, Münster.

Krüger, G., 1968, Die Apologien Justinus des Märtyrers, Minerva, Frankfurt.

Krusche, W., 1957, Das Wirken des Heiligen Geistes nach Calvin, VandenHoeck und Ruprecht, Göttingen.

Lake, K. ed., [1926] 1975, Eusebius: The ecclesiastical history, vol. I-II, Harvard University Press, Cambridge, MA

Marcovich, M., 1994, lustini Martyris Apologiae pro Christianis, ed. M. Marcovich, Walter de Gruyter, Berlin.

Marcovich, M., 1997, lustini Martyris Dialogus cum Tryphone, ed. M. Marcovich, Walter de Gruyter, Berlin.

Nigg, W., 1949, Das Buch der Ketzer, Artemis Verlag, Zürich.

Nilsson, M.P., 1974, Geschichte der griechischen Religion, Band II, Dritte Auflage, Beck, Munich.

Panagopoulos, J., 1977, Prophetic vocation in the New Testament and today, E.J. Brill, Leiden.

Powell, D., 1975, 'Tertullianists and Cataphrygians', Vigiliae Christianae 29, 33-54. http://dx.doi.org/10.2307/1582900

Reiling, J., 1973, Hermas and Christian prophecy: A study of the Eleventh Mandate, E.J. Brill, Leiden.

Reiling, J., 1977, 'Prophecy, the Spirit and the Church, in J. Panagopoulos (ed.), Prophetic vocation in the New Testament and today, pp. 58-76, E.J. Brill, Leiden.

Ritter, A.M., 1965, Das Konzil von Konstantinopel und sein Symbol, VandenHoeck und Ruprecht, Göttingen.

Ritter, A.M., 1968, 'Gregor von Nyssa "In suam ordinationem": Eine Quelle für die Geschichte des Konzils von Konstantinopel?', Zeitschrift für Kirchengeschichte 79, 308-328.

Ritter, A.M., 1972, Charisma im Verständnis des Johannes Chrysostomos und seiner Zeit, VandenHoeck \& Ruprecht, Göttingen.

Schepelern, W., 1929, Der Montanismus und die phrygischen Kulte, Mohr, Tübingen.

Schindler, A., 2009, 'Hagiographie und Hagiologie in Augustins Werk, vor allem in den Confessiones', in J. van Oort \& D. Wyrwa (eds.), Autobiographie und Hagiographie in der christlichen Antike, pp. 89-129, Peeters, Leuven

Schütz, J.H., 1981/ 1993, 'Charisma IV: Neues Testament', Theologische Realenzyklopedie, Band VII, pp. 688-693, Walter de Gruyter, Berlin.

Spittler, A.P., 1983, 'Testament of Job', in J.H. Charlesworth (ed.), The Old Testament Pseudepigrapha, vol. I, pp. 865-867, Darton, Longman \& Todd, London.

Stolz, A., 1926, 'Zu den Wunderkapiteln im XXII. Buch der Civitas Dei', Theologie und Glaube 18, 843-855.

Tabbernee, W., 2007, Fake prophecy and polluted sacraments: Ecclesiastical and imperial reactions to Montanism, E.J. Brill, Leiden. http://dx.doi.org/10.1163/ ej.9789004158191.i-485

Tabbernee, W., 2009, Prophets and gravestones. An imaginative history of Montanists and other early Christians, Hendrickson Publishers, Peabody, MA. 
Tabbernee, W. \& Lampe, P., 2008, Pepouza and Tymion: The discovery and archaeological exploration of a lost ancient city and an imperial estate, Walter de archaeological exploration of a lost ancient city and an imperia

Tertullian, 1952, Tertullien, Traité du Baptême, Texte, introduction et notes de R.F. Refoulé, (SC 35), Éditions du Cerf, Paris.

Thiselton, A.C., 2000, The First Epistle to the Corinthians: A commentary on the Greek text, Eerdmans Grand Rapids, MI.

Thiselton, A.C., 2004, 'The Holy Spirit in 1 Corinthians: Exegesis and reception history in the patristic era', in G.N. Stanton, B.W. Longenecker \& S.C. Barton (eds.), The Holy Spirit and Christian origins: Essays in honor of James D.G. Dunn, pp. 207-228, Eerdmans, Grand Rapids, MI.
Trevett, C., 1996, Montanism: Gender, authority and the New Prophecy, Cambridge University Press, Cambridge. http://dx.doi.org/10.1017/CBO9780511520587

Van der Linde, S., 1943, De leer van den Heiligen Geest bij Calvijn: Bijdrage tot de kennis der reformatorische theologie, Veenman, Wageningen.

Van Oort, J., 2011, 'The Holy Spirit and the early Church: Doctrine and confession', HTS Teologiese Studies/Theological Studies 67(3), 8 pages. http://dx.doi.org/10.4102/ hts.v67i3.1120

Vielhauer, P., 1961, 'Prophetie', Die Religion in Geschichte und Gegenwart, Dritte Auflage, Band V, pp. 633-634, Mohr, Tübingen. 